\title{
SOCIAL CAPITAL, MIGRATION AND SOCIAL INTEGRATION
}

\author{
Le Thi Mai \\ Ton Duc Thang University, Faculty of Social Sciences \& Humanities, \\ Department of Sociology, Hochiminh City, Vietnam
}

\begin{abstract}
Migrant marriage has been as a response to the globalized world. The important issue with regards to this research is to understand how immigrants integrate into the host for individuals and community development in this context. This paper focuses upon the ways in which social capital is utilizes to promote the integration of Vietnamese women marriaged to Taiwan husbands into their family and the host. Social capital constitutes "resources that can be used by the actors to realize their interests". Social integration is interpreted as being the process of inclusion and acceptance of individuals in a system, the creation of relationships among individuals and their subsequent attitudes towards society. This paper is based on a case study undertaken in 2014 on the Penghu Islands and in Taipei, Taiwan. Main findings: The values and norms of responsibility of women in family has been developed and practiced effectively by Vietnamese women marriaged to Taiwan husbands to integrate into their family. The regulations and legal environment for immigrants have created favorable conditions for their integration into the host. Traditional Vietnamese cooking skills are chosen by many Vietnamese women as a kind of social capital for their access to the Taiwanese job market. The social integration is reflected through: socialeconomic, culture integration and citizenship. It is hoped that research results are useful scientific basis for developing policies that promote the social integration of immigrants for the development of individuals and the social community.
\end{abstract}

Keywords: Social Capital, Social Integration, Vietnam-Taiwan Migration Marriage

\section{Introduction}

Migrant marriage in which one person migrates from his or her own country to the new spouse's country, has been as a response to the globalized world. The phenomenon of young rural women of the Mekong Delta Vietnam marrying foreigners, mostly from Taiwan and South Korea began in the 1990s when the 'Doi Moi' economic reforms opened Vietnam to foreign capital. This phenomenon has been developing over the past 30 years since the 1990s. More than their two generations have settled in Taiwan. Cross-border marriage has become a feature of Vietnamese integration into the global community. By 2010, the total number of Vietnamese women married to foreigners was over 80 thousand, 40 percent of whom were married to Taiwanese husbands (Han-woo \& Cuong, 2015). The newest statistical report of naturalized foreigners (excluding China, Hong Kong, and Macau) obtaining the citizenship of R.O.C. from Jan. 1, 2003 to Dec. 31, 2012 showed that among the 5,004 foreigners, $94.3 \%$ of them belong to foreign spouses with $77 \%(3,855)$ of the foreign spouses having immigrated from Vietnam. According statistics of Department of Household Registration Ministry of Interior (M.O.I, 2103), among the total number of naturalized spouses from Southeastern Asian countries, Vietnamese spouses account for almost 77\%. (YU Teng-Huang, 2014, p. 21). As former Minister of M.O.I., Lee Hong-yuan said, the rise in the divorce rate, $2.41 \%$ in 2013, the third highest in the world, could partly be ascribed to the increasing number of transnational marriages in Taiwan because a great number of foreign spouses either from Mainland China or Southeast Asian countries often have a hard time adapting themselves to Taiwan's culture or customs, leading to a high divorce rate among transnational couple ( $\mathrm{Wu}, 2013$, YU Teng-Huang, 2014). The important issue with regards to this research is to understand how immigrants integrate into the host for individuals and community development in this context. Therefore, the ways in which social capital is utilizes to promote the integration of Vietnamese

Corresponding Author: Le Thi Mai/ lethimai@tdt.edu.vn

$3^{\text {rd }}$ International Conference on Education, 20-22 April 2017, Kuala Lumpur, Malaysia 


\section{Le Thi Mai/Social Capital, Migration And Social Integration}

women marriaged to Taiwanese husbands into their family and the host and programs for the sake of empowerment, education were focused to provide these marriage immigrants are analyzed in this paper.

Using a wide range of literature that focuses upon the ways in which social capital have been found to promote or hinder integration of Vietnamese spouses into their husband's family, local communities in Taiwan. The following topics were found in the literature: the concepts, the role of social capital in social and economic integration, the influence of the host languages proficiencies and inter-ethnic contact in neighborhoods on building social capital, and how policy and legislative contexts affect development of social capital and then, facilitate migrants' social integration.

Bourdieu (1986), who first analyzed social capital systematically, defined social capital as "the aggregate of the actual or potential resources which are linked to the possession of a durable network of more or less institutionalized relationships of mutual acquaintance or recognition." It is important to mention the definition by Coleman in analyzing the role of social capital in migrant integration. Coleman defined that Social capital constitutes "resources that can be used by the actors to realize their interests" (Coleman, 1990, p. 305). To emphasize function of social capital that facilitate one's social integration, Coleman claim that social capital consists of some aspect of social structures that useful for certain action of actors within the structure. Thus, for social capital to exist, relations among persons have to be changed in order to facilitate action. At the meantime, Coleman also analyses the mechanisms that generate social capital (reciprocity expectations and group enforcement of norms), the consequences of possessing social capital (privileged access to information) and the social organization that provides the context for both resources and effects to materialize (Portes, 1998). According to Coleman (1990, p. 306), there are two main sources of social capital: consumerist motivation (internalized norms, bounded solidarity) and instrumental motivation (reciprocity exchange, enforceable trust). The expectation of reciprocity by those who agreed to provide someone with access to information depends on how far the person making the claims feels obliged to repay, when and in what form. This depends on the level of trustworthiness of the social environment. Thus, social capital functions among other things as a source of control (Coleman, 1990) and a source of resources mediated by non-family networks (Bourdieu, 1986), facilitating access to jobs, market and loans. These view is similar to concept by Bourdieu and Wacquant (1992, p. 119), "Social capital is the sum of the resources, actual or virtual, that accrue to an individual or a group by virtue of possessing a durable network of more or less institutionalized relationships of mutual acquaintance and recognition". It was said that people access to social capital through membership in interpersonal networks and social institutions and then convert it into other forms of capital to improve or maintain their position in society (Bourdieu, 1986, Coleman, 1988).

"Migrant networks are sets of interpersonal ties that connect migrants, former migrants, and non-migrants to one another through relations of kinship, friendship, and shared community origin. Network connections increase the likelihood of international migration because they lower the costs and risks of movement and increase the expected net returns to migration. Having a tie to someone who has migrated yields social capital, people can draw upon to access to an important kind of financial capital". (Alberto Palloni, et al,. 2001, p. 1263-1264)

Burt (1997) suggests that social capital is a quality of individuals; it contributes to an individual's human capital, while Yli-Renko, Autio and Sapienza (2001) examined social interaction, relationship quality and network ties as dimensions of social capital. Social interaction is necessary to establish the network ties and relationship quality defines the strength of those ties. These three dimensions of social capital help to produce competitive advantages.

Kitching et al., described ethnic diasporas as a form of social capital by defining social capital not only as 'resources', but also as 'opportunities available to agents occupying particular positions' (2009, p. 694). Thus, evaluating the quality and variety of social ties and networks is crucial in assessing the usefulness of social 
capital. Dahinden (2013), analyzed network social capital as one possible form of social capital and an asset in a network to underline the importance of resources (variety and quality of contacts) are available in networks. It sounds that the more differentiated social relations, the better the quality of social capital. Those networks are characterized by a high variety of diverse ties, both 'strong and weak ties' (Granovetter, 1973). As social beings, humans are inevitably enmeshed in interpersonal webs of strong ties to close friends and relatives and weak ties to more distant relatives, casual acquaintances, and friends of friends. By drawing on the social ties, an individual can mobilize the social capital embedded within it to gain valuable information, moral support, and material assistance. (Gunawan Prayitno et al., 2014).

Social integration is defined as the harmonious and coherent processes of the structure of a social system (Koramaz, 2014). Social integration is the stability of relations among parts within a system like whole (Le, 2014). Social integration is interpreted as the process of inclusion and acceptance of individuals in a system, the creation of relationships among individuals and their attitudes toward society. Social integration is also further developed as structural integration (e.g. the acquisition of rights and the access to position and status in the core institutions of the host society); Cultural integration; Interactive integration (e.g. the acceptance and inclusion of immigrants in the primary relationships and social network of the host society) and identification integration (e.g. inclusion in a new society on the individual level. It is reflected by a feeling of belonging to the host society and identifying with it) (Bosswick \& Heckmann, 2006). Additionally, cultural integration also can indicate how much engagement they conduct through their abilities in the local community or the extent of integration with their family members in Taiwan. Vietnamese spouses' self-identity has the possibility of double belonging because of their constant contact with their natal home or through their remittances.

The literature shows that social networks do play a significant role among migrants in the initial settlement process, helping to find a job or accommodation and giving support - especially buffering to some extent the negative effects of weak cultural and economic capital, as well as lack of a stable legal status. At this stage ethnic networks do constitute a source of bonding social capital. With time, these can lead to the development of ethnic places, such as shops, business and restaurants, where migrants and native inhabitants meet, and which can then become a source of bridging social capital. The extension of good quality ethnic networks, based on strong ties and mutual trust (which thus constitute bonding capital), via weak ties to wider social networks, seems to provide the best of the two types of capital - in an optimal form of providing opportunities for chance encounters, leading to attachment to place and social integration. The overview of the literature studying the role of social capital in the social integration of migrants at the local level has demonstrated the importance of taking a broader spatial perspective. Not only in terms of actual research, showing the importance of the broader context, including the institutional context, but also in terms of policy design and implementation.

In this paper, my concern is to deepen our understandings of the socialization of immigrant women, specifically focusing on immigrants to Taiwan. Some Vietnamese scientists (An et al., 2005, the Vietnam Committee of Population, Family and Children in 2005) comment that less examination exists on Vietnamese marriage migrant life in their husband's homes due to limited finance curtailing the ability to conduct surveys in Taiwan. We hope that the findings of this research conducted in Taiwan will fills a gap in the previous literature on this limitation, giving the reader an objective and lively insights. The existing research outlined in this section contributed greatly to the conceptualization of this paper and is drawn upon throughout the article in order to illustrate, support and query our own findings.

\section{Methodology}

We used a qualitative methodology to guide this study because marriage/family itself is a complicated construct established, formulated and transformed by, through and within social practices. The specific research methods include: in-depth interview, group discussion, participant observation. During the research, 


\section{Le Thi Mai/Social Capital, Migration And Social Integration}

we observed the informants' activities, participating in their normal life and listening to their stories, organized some travels, having lunch in their restaurants or visiting their homes in the evenings whenever permitted. A two-hour in-depth interview was conducted in Vietnamese. The time could be adjusted according to circumstances. We interviewed some informants several times due to the need for more information and for exploring the new themes noticed from previous interviews. Additional, we used also semi-structured interview to interview some related parties, such as the husbands and in-laws, neighbors or villagers, to collect data during visiting their homes. Our work experiences and networks had been useful resources for carrying out the interviews: we are working with lecturers and researchers in National Penghu University (NPU) and the Vietnamese students who were studying in NPU, Mango, Pengho Islands, Taiwan.

Recruitment of informants and sampling methods. Informants were recruited from two sources. First, through the introduction of our students studying at NPU in Penghu Islands and National Cultural University in Yang Min Shan, Taipei, we went to see Vietnamese women married to Taiwanese husbands. They have reputation in the Vietnamese women's community there. A snowball sampling method was developed then, to trace the social networks of the informants and as well to find new interviewees of which 26 informants were met through this method. Five interviewees were met randomly in the fieldwork. These 31 Vietnamese women were identified as key informants. The selection criteria of these informants included: all informants were involved in Taiwan-Vietnamese marriages; being from different social backgrounds, including farming, small trader, worker, education attainment, self-employment, and all informants married Taiwanese husbands after the "Doi moi" attracting foreigner investment in 1990s. We considered these standards important because it not only symbolized globalization but also the beginning of rapid social changes in Vietnam.

Profile of research participants. Maximum variation of data was also given attention in our consideration and it "aims to select cases that provide for wide variations in the experience or processes being examined. Various attributes such as age (from 25 to 46 years old), educational level (from primary school to the student of university), social class (up to middle class) and occupation before marriage were taken into account and also identified as important factors. We introduced our research topic and purpose to the informants and obtained their consent for interview and recording.

\subsection{Terminology}

Coleman's definition is used as working one here by which Social capital is defined constituting "resources that can be used by the actors to realize their interests" (Coleman, 1990, p. 305). Social capital of Vietnamese marriage immigrants is identified two dichotomy categories: individual/cognitive social capital and general/structure one. Their individual social capital was examined by the filial daughters socialized in Vietnam as: traditional cooking skills, take care all members in the family specially children, obedience to the mother-inlaw, be responsible to both natal family and husband's family, faithful, honest, very diligent about earning money, tolerant of hardship, and Mandarin proficiencies before their marriage.... Their general/structure social capital was examined by daughters of shared origin, casual friends, acquaintances, even friends of friends who have been got marriage to Taiwanese husband prior to Taiwan as well as Taiwanese governmental procedures and regulations as favorable conditions for them to integrate into the host such as Mandarin language courses, vocational courses before they want to start a small business or work at anywhere. Social integration here is the stability of relations among parts within a system like whole (Le, 2014, Le et al, 2017, p. 62-63, 72 in detail).

\subsection{Theoretical Approach}

Social network analysis was used in this research to show how Vietnamese brides took advantage of relationships, experiences and opportunities to empower themselves to access social integration and achieve their goals. For example, social network analysis was used to show how Vietnamese brides access social 
resources and supports such as courses for learning the Mandarin language and other training courses that the Taiwanese government opened up for them to improve their capacity. Crucially, these endeavors also enabled Vietnamese brides to access the labor market or participate in social activities. The sustainable livelihood approach was used in this research to analyze why the majority of rural women in South Vietnam chose marriage to foreign husbands as a strategy to escape poverty, a means to get the financial capacity of their own to support Vietnamese natal families, even as a means increase their social mobility and ascend to a higher social class. (Le et al., 2017, p. 63-64 in detail). These views were conceptualized and reflected within the content of in depth interviews, group discussions and fieldwork observations.

\section{3. Data}

Research information in this paper is mainly derived from interviews and observations conducted in 2014. The analyses here were based on information from 31 Vietnamese immigrant spouse marriage Taiwanese husband between the periods 1990-2014 who are settling in the Penghu or Pescadores Islands and Taipei for at least 5 years. This investigated was ethnographic in approach, involving months of intensive participant-observation and we actively participated in community activities involving members from transnational marriage families. Connections were continued by mobile phone, face-to-face interviews when they came back Vietnam. (Le, 2017: 64 in detail).

\section{Results}

3.1. The values and norms of responsibility of women in family has been developed and practiced effectively by Vietnamese women marriaged to Taiwan husbands to integrate into their family.

To build confidence within the husband's family, it is not an easy process. It chiefly depends on the individual woman and her willingness to work hard, exhibit respect and gain trust. Information from group discussions conducted in Magong City, on the Penghu Islands revealed the initial difficulties associated with building these relationships. Popular behaviors of Vietnamese brides in this first period involved them trying their best to satisfy the husband and the husband's family members by responding to their expectations.

When I came here, I was so sad and homesick, my husband is very gentle. My husband's family once had a fishing boat going to the sea, now he works as a wall-paint man. At that time, my mother in law is old and too sick to go. I had to take care for her daily meanwhile I am suffering from vomiting by being pregnant. Forced by no one but being Vietnamese bride, I wake up at 6 am every morning to cook vegetarian for mother-in-law to eat, cook porridge, cook food for all members in husband's family to eat. I remember at that time money was not available. Then I just nursed my new baby and took care of mother-in-law seriously. Everyday I had to suck out phlegm, to wear diapers, change up, bath and shampoo her. I did it from my heart. My mother-in-law was very gentle and she loved me too. I worked hardly up to 36 hours daily... money was very tight,... (49 years old, from Phu Yen province, the Middle Vietnam)

What I need is chances and I always believe that my chances are here. It is too poor to be a farmer, so many poor rural girls like us without much education and skills, have preferred to being migrant spouse. It all depends on how well I meet my husband family's expectations for a daughter in law. I have known the marriages of some Vietnamese spouses are unsuccessful, not as they expected. Most of them sacrifice and suffer for the happiness of their children. They have worked hard to achieve the goal. In case of divorce, they try to fulfill the responsibility of caring for children and meet the conditions for their children to go to good quality schools. "Do it all for our children" is a statement that is often heard (46 years old, from Saigon City).

The informants had expressed different thoughts and ideas on daughters' filial roles. According to their perceptions of filial piety, "sending money back home" was of great significance for them. Their conversations could be categorized into three overlapping themes: 1) The "remittances" theme came from those who felt 


\section{Le Thi Mai/Social Capital, Migration And Social Integration}

guilty about their absence from physical care of parents, so they wanted to remit their natal parents as a compensate; 2) The "status" theme came from those who considered that sending money home was a way to indicate their financial capability and a means to improve their status at home as well; 3) The "face" theme came from those who had associated the activity of sending money home with the "face" issue. At the same time, with the remittances from the migrant daughters, the parents and siblings also gained more chances to achieve some development. Reciprocally, they would help to increase their daughters' status in their husbands' families. Following are their voices from a group discussion in Penghu Islands:

Every time I visit home (in Vietnam), I always gives some money to my parents... just want to show my small gratitude, reducing my worry (36 years old, from Quang Ninh province, the North Vietnam ); Through giving money to parents, I also want them to know that my life here is good, so they do not need to worry about me (33 years old, from Dong Nai province, the South Vietnam). How can a daughter live a comfortable life while turning a blind eye to her parents' poor life? My parent's house is build by my remittance for 3 years. They are proud of me,... Then, villagers often conversed with my mother "Your daughter is so filial". Many beautiful houses in my natal village belong to those families have daughters abroad. Of course, there are also brides who cannot make any contribution to their families. People around will spread the gossip like "she has married a terrible guy" or "she has been trafficked into prostitution." The parents will also lose face (46 years old, from Can Tho province, the South Vietnam). I am sent money to both my parent and parent-in-law monthly. My husband is becoming belief in me. Both sides of parents are equally important. My business run effectively due to support of my husband's family (49 years old, from Phu Yen province, the Middle Vietnam).

3.2. The regulations and legal environment for immigrants, Vietnamese immigrant spouse network are considered as dimensions of structural social capital that have created affiliated conditions for their integration into the host. The social integration is reflected through: citizenship; social-economic and culture integration.

Under the provisions of the Taiwan Government, Vietnamese wives who first arrived in Taiwan, had to apply for temporary residence registration immediately. The wife's application must be signed by her Taiwanese husband in the role of her guarantor. At the same time, Vietnamese brides often enrolled in Mandarin language classes organized by local authorities to support them. A Vietnamese lady teaching in these classes explained:

"There were classes for Vietnam brides. They teach two languages as Vietnamese - Mandarin or Mandarin Vietnamese. Since Vietnamese women married Taiwanese men were very much. I completed that course and was granted Certification. Now I do enrichment teacher Vietnamese to children and adults here". (Le, 2017, p. 67 in detail)

A Vietnamese spouse of 36 years old from natal village in Long An province said

Here they organize courses for "new residents", for those who come from other countries to Taiwan. There are also many activities, such as: I am now studying interpreting classes, yoga classes. Each month also held an afternoon meeting for the Vietnamese spouses clustered talking and eating. They make biscuits and tea for us to eat, drinking and talking together. My children are young, a son of second grader, and a girl of third grader. So, I have to guide them learning... sometimes my husband did not agree to let me to the meeting. Every time I meet my friends at those meetings, I am very happy, reduces my homesickness. We exchange with each other about work, family life, and especially happy if someone returns to Taiwan after a visiting native family, there are many things to say.

Voice from Vietnamese spouses themselves reflected that the local government has not only created a useful legal environment that facilitates the need for them to integrate into society but also organized activities to cater to their spiritual needs. In a group discussion, a woman of 38 years old from Soc Trang province of Vietnam told us that: 
"My village was named "Taiwan Island" because roughly 90\% its daughters married Taiwan husbands. We have each other's phone numbers to contact. We often inform each other of new government regulations that relate to us and all that is needed to help from our friends.".

Another Vietnamese spouse of 36 years old, from Quang Ninh province said:

At first period, I did not know how to read Mandarin, just say a few sentences so it's totally up to the husband. Since going to class of Mandarin, I feel comfortable and confident in communication with my husband, other family members and neighbors. After 3 years, I was granted ID by local authorities. I studied a vocational training course and now am a worker in a seafood processing facility. In Taiwan, anyone who wants to go to work, regardless of job, must attend a vocational training.

A Vietnamese spouse of 49 years old, coming Taiwan from Phu Yen province said:

Most of rural Western Mekong Delta women married Taiwanese in Penghu. I told the newer the rules and procedures of the Taiwan Government so that they can quickly get the certificate... I helped some women who met difficult from their husbands by giving them civil statuses to my family so that they were eligible for ID. I got some women to work in my restaurant when they have not found suitable jobs yet... With the support of local authorities, I am mobilizing Vietnamese brides here to take place in community activities to meet the requirements of local government for establishing the Vietnamese Association in Penghu.... Lecturers at the National Penghu University are very enthusiastic in teaching classes for foreign women marrying Taiwanese. They help us a lot. These short-term classes provide the basic knowledge necessary for those who want to go to work. The government requires the certificates needed for each job....

The economic incorporation of Vietnamese immigrant spouses provided a useful illustration of whether migrant networks can be beneficial. Along the street 111 Taiwan Taipei city, Shihlin District, Dexing East Road, there are 10 food outlets/restaurants, of which about $50 \%$ are owned by Vietnamese immigrant spouses. Employers often help newcomers by getting them to work for living. Each month they earn about 21 thousand Yuan, working from 8 to 10 hours per day. Customers are both Vietnamese and local people. They come here not only to eat Vietnamese dishes but also to meet and communicate to each other the experiences of success and failure. This is evidence of the way in which immigrants have used their social networks and co-ethnic social capital to participate in labor markets. Niche employment in retail, restaurants, and services (nail shop, etc.) are common in Vietnamese immigrants female spouse here.

3.3. The social integration is reflected through: social-economic, culture integration and citizenship. Traditional Vietnamese cooking skills are chosen first of all by many Vietnamese migrant spouses as a kind of social capital for their access to the Taiwanese job market, even for social mobility.

Out of the 31 informants, 17 considered their earning ability had increased after their marriages. The latters agreed that there were job opportunities in Taiwan came more easily regardless of their socio-economic backgrounds and they were able to find work in spite of being limited in skills and education. However, they all talked about the opportunities brought by mobility with what were socialized in Vietnam. Vietnamese migrant spouses began running their own businesses in order to build up not only their financial basis to send more money back to their natal families but also to elevate their social statuses from within Taiwan. Following is story of Vietnamese migrant spouse as a case:

I was born in Phu Yen, Nha Trang province, Vietnam. Being the youngest in my family, I am loved by all. Then, I and my family migrated to Saigon and traded. I was used to run a business of video cafes. Because of the sad love story, I wanted to go away and then got married to Taiwanese man by my friend's introduction. My husband' family was so poor. My children were young, the husband' younger sister gave a birth. My mother-in- 


\section{Le Thi Mai/Social Capital, Migration And Social Integration}

law was sick and then, I alone had to take care daily for 4 children and an elderly in big family. After the death of mother-in-law, we had no money, we were bickering each other daily, I decided to go outside to work.

I did not expect to get rich over night and would be satisfied with some money. It all depends on my work hard. At that time, I worked all day for earning only 8,000 Yuan. Finally, to escape difficult poor life, I called back my older brother in Vietnam to learn how to cook "Pho" a kind of Vietnamese traditional beef noodle for sale. I rent this store just sell "Vietnam Pho Restaurant", just look after the baby. Ten years ago, the store did not have a restaurant brand. The "Pho" is cooked quality, customers like then, they go online advertising it... At that time I have some acquaintances as the lecturers in National Penghu University (NPU), whenever the school has any activities, I go there to cook or make Vietnamese dishes brought there inviting them to eat and to advertise as well. Students and teachers there also advertised it, and the shop started to freeze. Taiwanese guests write multiple postings. Many films about life of Vietnamese spouses in Taiwan are producted (https://www.youtube.com/watch?v=2d-hTLHKteg,

2015 , https://www.youtube.com/watch?v=72cb50qy8Ic\&t=60s.). I actively encourage Vietnamese women here and join them in activities related to the local election event and organize parties for Christmas or Mid-Autumn Festival for children. Especially now I am focusing on fulfilling the conditions for the establishment of the Vietnamese Women's Union in Penghu.

Now it seems to say that difficulties have passed, I have fulfilled obligations to children and husband. I now focus on how to earn enough money for my children to attend high quality schools. My son is in $9^{\text {th }}$ grade 9 and my daughter is $7^{\text {th }}$ grade. What I possess today, besides my own efforts, results from the help of the kindhearted Taiwanese, from the local government. I try my best to contribute to the development of the Vietnamese community here as well as the Penghu community and Taiwan in general.

When doing fieldwork in community, one positive comment we often heard about Vietnamese spouses was capable. In the traditional definition, capable mainly referred to a wife's excellent abilities and skills to manage household chores and duties. However, in conversations with our informants, we found that in addition to the traditional definition, capable was also associated with a Vietnamese spouse's ability to make money. They were smarter at finding money though not all these wives came from prosperous families. They had been aware of the opportunities brought by practice social capital for their access to the Taiwanese job market and taken steps earlier than others to engage in relevant family businesses.

\section{Conclusion and discussion}

There are many researches related to Vietnamese spouses living in Taiwan. Most of them found negative impressions of "foreign brides", particularly those who come from relatively poorer countries. (Hsia, 2010, Wang \& Hsiao, 2009). Contrary to the most of results that explored in last researches, findings in this case study have shown that what Vietnamese migrant spouses participated in this study need is a chance to create a change for their better life. Migrant marriage was chosen as a means by them. Migration is becoming more and more common in the globalized world. It is important then, is to understand how immigrants integrate into the host and what makes sense is to create the affiliated conditions for migrants to integrate into the host for their development so that they contribute effectively to the host society.

During the fieldwork we found that informants became more talkative and comfortable after having met several of them together in their familiar environment. For example, the "Vietnam Pho Restaurant" run by a Vietnamese spouse from Ho Chi Minh City near 北辰市場 (Beichen) Market was a popular place for many Vietnamese spouses to hold regular or occasional parties and gatherings and exchanging gossip. These events were good opportunities for us to make participant observations and to hear different voices and stories from them. 
Evidences from this study reflected Vietnamese migrant spouse's acumen in taking advantage of social capital that was socialized in Vietnam and negotiating difficulties to integrate to the host. In public opinion, Vietnamese spouses are often viewed as pragmatic women who care only about money rather than love. If Vietnam spouses are looking for money, why would majority of them got married to poor rural Taiwanese men? The intimate practices of these spouses within marriages have indicated that they are not country bumpkins but women with both traditional and modern-oriented values. They are smart women who are aware of the market logic and care a lot about filial daughter and self-development. Above all, they are aware that they can perform their femininities as "Vietnamese brides" in this marriage to serve their ends. What "Vietnamese brides" care about is not the exact amount of money but the future-orientated meanings associated with the money. This could explain why some Vietnamese brides were satisfied with not so rich Taiwanese husbands. For them, money is important but it is also relative although they try to grasp possible chances for better life.

Most of Vietnamese migrant spouses have shown great adaptability to new circumstances, successfully renegotiating their identities in the host. The findings from interviewing these Vietnamese participants gained more insight into the new social networks constructed by Vietnamese spouses from the dynamic of empowering themselves through working or running their own businesses in the host society, and of creating a wide variety of interactions with locals or local communities. In conversations, there is a strong desire for development. Although many of these Vietnamese spouses had achieved certain benefits, opportunity, and autonomy through their marriage mobility, gender had always been a vital factor in shaping their intimate relationships and family responsibilities. Financial capability played an important role in affecting their bargaining power within the marriage. The differences among Vietnamese spouses, in their varied marital concerns and strategies were not only cultural, but also attributable to the material conditions under which these relationships were forged and negotiated. Vietnamese spouses who did not get the marriage as their expectation because of the reasons from Taiwanese husbands (such as domestic violent, unemployment, sickness,...) were suffering for the happiness of their children. In the case of divorce, most of them are responsible for raising children without any from their children's fathers.

Proccess of social integration of Vietnamese migrant spouses to Taiwan in this study supports claim of Kim Y that, diaspora is a place of identity, living with, living through difference, and the diaspora are always producing themselves anew. Identity is always in process, always constituted within and it must be negotiated. The nature of diaspora involves identity as a subjective condition marked by contingency, differences of power and position, internal differentiation, inner conflict and contestation, indeterminacy and continual construction (Kim Y, 2011: 10). An immigrant's lack of citizenship may limit Vietnamese migrants spouse's access to destination-country institutions and organizations. This limitation then, would be addressed by government interventions in the capacity building for immigrants. It is hoped that these findings will shed light on the difficulties of these Vietnamese migrant spouses and also benefit current and future immigrants to overcome such difficulties and to better adjust themselves to living in Taiwan. Efforts to overcome the difficulties and differences to integrate into the Taiwanese society of Vietnamese migrant spouses is the source of inspiration of films and reporters,... Example: 澎湖另一種家鄉味 (Penghu - A hometown flavor) producted by Ministry of Internal Affairs, Director: 陸孝文 (Luc Hieu Van), 2015, https://www.youtube.com/watch?v=2d-hTLHKteg. The protagonist of the film is one of the Vietnamese migrant spouses who participated in our survey. This film contributes to increase the reliability and vibrancy of the findings of this article.

With the influx of new marriage immigrants coming to Taiwan since the 1990s, to help them to settle down in Taiwan, it should be taken a bottom-up or grass-rooted approach through research and then action taken from the results gathered from research and through focus on aspects such as the conditions for these Vietnamese migrant spouses to engage in governmental activities and to develop more suitable methods to assist these spouses in overcoming some of their current social problems such as mal-adjustment to a new society, 


\section{Le Thi Mai/Social Capital, Migration And Social Integration}

something which definitely affects the value of their lives after emigrating to Taiwan. The results of this survey also suggest the need for research and implementation of projects, such as the capacity building project for the social integration of migrant women; Assess the socioeconomic contributions of immigrants to Taiwanese society and the role of interventions and supporting of government in relation to immigrants' contributions to individual and community development from a gender perspective.

\section{Acknowledgements}

This research is funded by the Foundation for Science and Technology Development of Ton Duc Thang University (FOSTECT), website: http://fostect.tdt.edu.vn, under Grant FOSTECT.2015.BR.21. We also appreciate and say thanks those Vietnamese women married Taiwanese men had agreed to participate in this survey. We would also like to thank the help of our graduated students and colleagues in Taiwan. Without their enthusiastic and effective cooperation, we could not carry out this study. We would like to express our sincere thanks to Dr. Dominic Hewson, an Irish colleague for English editing and proofreading of this article.

\section{References}

Alberto Palloni, Douglas S. Massey, Miguel Ceballos, Kristin Espinosa, and Michael Spittel., 2001, Social Capital and International Migration: A Test Using Information on Family Networks. American Journal of Sociology, Vol. 106, No. 5 (March 2001), pp. 1262-1298.

Bosswick, W., \& Heckmann, F., 2006, Integration of migrants: Contribution of local and regional authorities. European Foundation for the Improvement of Living and Working Conditions.

Bourdieu, Pierre, and Loic Wacquant., 1992, An Invitation to Reflexive Sociology. Chicago: University of Chicago Press.

Bourdieu, Pierre., 1986, "The Forms of Capital." Pp. 241-58 in Handbook of Theory and Research for the Sociology of Education, edited by John G. Richardson. NewYork: Greenwood Press.

Burt, R.S., 1997, "The Contingent Value of Social Capital." Administrative Science Quarterly 42, 339- 365. Coleman, J.S., 1990, Foundations of Social Theory. Cambridge: Harvard University Press.

Coleman, James S. 'Norms as Social Capital', in Gerard Radnitzky and Peter Bernholz (eds), Economic Imperialism: The Economic Approach Applied Outside the Field of Economics, New York: Paragon House Publisher. 1988; 133-55.

Dahinden, J., 2013, 'Cities, migrant incorporation, and ethnicity: A network perspective on boundary work', Journal of International Migration and Integration, 14(1): 39-60.

Granovetter, M., 1973, 'The strength of weak ties', American Journal of Sociology 78(6): 1360-1380. Grzymała-Kazłowska., 2005, 'From ethnic cooperation to in-group competition: undocumented Polish workers in Brussels', Journal of Ethnic and Migration Studies, 31(4): 675-697.

Gunawan Prayitno, Kakuya Matsushima, Hayeong Jeong and Kiyoshi Kobayashi., 2014, Social Capital and Migration in Rural Area Development. Procedia Environmental Sciences 20 (2014) 543 - 552.

Han-woo, L. \& Cuong, B. T. (2015). Việt Nam - Hàn Quốc: Một phần tư thế kỷ chia sẻ cùng phát triển Nhà xuất bản Đại học quốc gia Tp. Hồ Chí Minh (Vietnam - South Korean: A quarter of a century of shared development. Publisher of Vietnam National University, Ho Chi Minh City)

Hsia, H.-C. (Ed.)., 2010, For better or for worse: Comparative research on equity and access for marriage migratns. Hong Kong: Asia Pacific Mission For Migrants.

Kim, Y., 2011, Transnational migration, media and identity of Asian women: diasporic daughters. New York: Routledge. 
Kitching, J., Smallbone, D. and Athayde, R., 2009, 'Ethnic diasporas and business competitiveness: minorityowned enterprises in London', Journal of Ethnic and Migration Studies, 35(4): 689-705.

Koramaz, E. K., 2014, The spatial context of social integration. Social indicators research, 119 (1), 49-71

Le Thi Mai, 2014, Social Integration of Vietnamese People Residing Abroad. International Conference Proceedings. ISBN: 978-969-9948-01-5. P. 534-577.

http://www.globalilluminators.org/wp-content/uploads/2014/09/409.pdf.

Le Thi Mai, Bui Loan Thuy and Do Xuan Ha, 2017, Social Integration of Vietnamese Women Married to Foreigners (Case Study in Penghu Islands and Taipei, Taiwan). Journal of Management and Marketing Review. Vol 2 (1) 59 - 74 (2017). ISSN 0128-2603 @ 2017.

Phan, A., Phan, Q. T., Nguyen, Q., 2005, Hiện tượng phụ nữ Việt Nam lấy chồng Đài Loan Thành phố Hồ Chí Minh. Nhà xuất bản Trẻ (The phenomenon of Vietnam women married Taiwan Husband. Ho Chi Minh City. Young Publisher)

Pengli HUANG (黄鹏丽), 2014, Gender, Mobility, and the Space in-between: Vietnamese Brides Negotiating the Boundaries of Tradition and Modernity at the China-Vietnam Border. for the Degree of Doctor of Philosophy at The University of Hong Kong. in November 2014

Portes, 1998, 'Social capital: Its origins and applications in modern sociology', Annual Review of Sociology 24: $1-24$.

Tien, C. Y., \& Wang, H. Z., 2006, Masculinity and cross-border marriages: Why Taiwanese men seek Vietnamese women to marry? Taiwan Journal of Southeast Asian Studies, 3(1), 1-36. (in Chinese)

Wang, H.-Z., \& Hsiao, H.-H. M. (Eds.), 2009, Cross-border marriages with Asian Characteristics. Taipei, Taiwan Academia Sinica, Center for Asia-Pacific Area studies

Wu, S., 2013, Talk of the Day -- Transnational marriages and divorce rate. Central News Agency.2013-08-26. http://www.taiwannews.com.tw/etn/news_content.php?id=2287379

Yli-Renko, H., E. Autio, and H.J. Sapienza, 2001, "Social Capital, Knowledge Acquisition, and Knowledge Exploitation in Young Technology-Based Firms". Strategic Management Journal 22, 587-613.

YU Teng-Huang, 2014, Vietnamese Spouses' Cultural and Social Identity in Taiwan. A Dissertation for the degree of Doctor of Philosophy in Asia Pacific Studies. Ritsumeikan Asia Pacific University. Beppu City, Japan.

陸孝文 (Luc Hieu Van), 2015, 澎湖另一種家鄉味 (Penghu - A hometown flavor)

https://www.youtube.com/watch?v=2d-hTLHKteg; or https://www.youtube.com/watch?v=iDNvRanLSTs. Date of access: 21/11/2015.

30分鐘 蜻蜓 https://www.youtube.com/watch?v=8X0iIKGpgDA Date of access: 21/11/2016.

10分鐘澎湖的家鄉味https://www.youtube.com/watch?v=72cb50qy8Ic\&t=60s. Date of access: 21/11/2016. 